\title{
DYNAMICS OF SOME LIMNOLOGICAL CHARACTERISTICS IN PACU (Piaractus mesopotamicus) CULTURE TANKS AS FUNCTION OF HANDLING
}

\author{
SIPAÚBA-TAVARES, L. H., MORAES, M. A. G. de and BRAGA, F. M. de S. \\ UNESP/Centro de Aqüicultura, Rodovia Carlos Tonnani km 5, CEP 14870-000, Jaboticabal, SP, Brazil \\ Correspondence to: Lúcia Helena Sipaúba-Tavares, UNESP/Centro de Aqüicultura, Rodovia Carlos Tonnani km 5 , \\ CEP 14870-000, Jaboticabal, SP, Brazil \\ Received May 5, 1998 - Accepted September 8, 1998 - Distributed December 22, 1999
}

(With 2 figures)

\begin{abstract}
In order to study the water quality in fish tanks, a 166-day (January to July 1992) experiment was realized using the indigenous species "pacu" (Piaractus mesopotamicus). Two different protein levels were tested in the diet (16\% and 34\% crude protein) and three stocking densities $(0.25,0.50$ and 0.77 fish $/ \mathrm{m}^{2}$ ). From the results, it was observed that the interactions between stocking density and experiment length affected the characteristics bicarbonate and alkalinity, as well as the interaction between stocking density and protein levels affected concentrations of free and total $\mathrm{CO}_{2}$, conductivity and $\mathrm{pH}(\mathrm{P}<$ $0.05)$. The water temperature in tanks changed significantly during the period of study $(\mathrm{P}<0.05)$, decreasing gradually from summer to winter. There was no significant difference in water residence time in the tanks $(\mathrm{P}<0.05)$ during the experiment. The other limnological characteristics were not affected by treatments during study period.
\end{abstract}

Key words: stock density, protein levels, fish tanks, pacu, limnological characteristics.

\section{RESUMO}

Dinâmica de algumas variáveis limnológicas em tanques de cultivo de pacu (Piaractus mesopotamicus) em função do manejo

Visando obter subsídios para um estudo da qualidade da água em tanques de piscicultura, realizouse um experimento de 166 dias com uma espécie nativa, pacu (Piaractus mesopotamicus). Nos tanques foram testados dois níveis diferentes de proteína na dieta ( $16 \%$ e $34 \%$ de proteína bruta) e três densidades de estocagem $\left(0,25 ; 0,50\right.$ e 0,77 peixes $\left./ \mathrm{m}^{2}\right)$. Dos resultados obtidos foi observado que a interação entre a densidade de estocagem e a duração do experimento interferiram nas variáveis bicarbonato e alcalinidade e a interação entre a densidade de estocagem e a porcentagem de proteína interferiram nas concentrações de $\mathrm{CO}_{2}$ livre e total, condutividade e $\mathrm{pH}(\mathrm{P}<0,05)$. A temperatura da água nos tanques variou significativamente ao longo do período estudado $(\mathrm{P}<0,05)$, diminuindo gradativamente do verão para o inverno. Não houve diferença significativa no tempo de residência da água nos tanques $(\mathrm{P}>0,05)$ durante a duração do experimento. Os demais parâmetros não sofreram interferência dos tratamentos ao longo do período de estudo.

Palavras-chave: densidade de estocagem, níveis de proteína, tanques de piscicultura, pacu, variáveis limnológicas. 


\section{INTRODUCTION}

The principal causes that water quality is highly affected are uneaten feed and partially digested feed or faecal matter. These components become polluters by loading the environment with an excess of phosphates and/or nitrates and other additives (such as antibiotics) which have been incorporated into the feed (Silva \& Anderson, 1995).

Fish excreted phosphorus in a variety of forms, generally divided into soluble and particulate forms. The soluble forms, organic phosphorus and phosphate affect water quality directly. The particulate forms, on the other hand, accumulate in the sludge and release phosphorus slowly.

Thus feeding management, associated to fish density can cause changes in the availability of nutrients inside the tanks and, consequently, in the fish production.

Problems with the environment are frequent in fish tanks because of the excess of feed given. This can cause excessive bacterial production, leading to oxygen consumption during decomposition. However, inorganic components can be released into the environment, $\mathrm{N}$ and $\mathrm{P}$ in particular, favoring phytoplanktonic growth.

Effective manipulation of the environment in favor of fish production requires basic knowledge of physical, chemical and biological processes. With this in mind, research that leads to a greater understanding of these dynamics is of great importance for fish culture studies.

The present study proposed to evaluate the effect that three different fish densities, using two levels of crude protein in their diet, had on the water quality in the fish tanks.

\section{MATERIALS AND METHODS}

\section{Study area and data}

The present study was executed at the Aquaculture Center of São Paulo State University, from January to June 1992, totaling 166 days.

Six fish tanks, $54 \mathrm{~m}^{3}(5.0 \mathrm{~m} \times 9.0 \mathrm{~m} \times 1.2$ $\mathrm{m})$, contained pacu (Piaractus mesopotamicus) fingerling were studied. Initially, the fish had a mean weight of $43.35 \mathrm{~g}$ and an mean length of $15.38 \mathrm{~mm}$.

Two treatments were applied to each of the six fish tanks, testing the protein factor $(16 \%$ and $34 \%)$ and the density factor $(0.25,0.50$ and 0.75 fish/ $\mathrm{m}^{2}$ ), totaling six different combinations (protein $\times$ density) (Table 1) using pressed pellets twice a day.

Water samples were monitored every fifteen days in all ponds and all samples were collected between 08:30 and 10:30 hours, using a Van Dorn bottle $(5 \mathrm{~L})$ and always at the same location and depth of $0.60 \mathrm{~m}$.

The temperature, measured with an Inconterm thermometer, and water transparency, using a Secchi disk, were taken in situ. The $\mathrm{pH}$ and conductivity were analysed in the laboratory with a Quimis $\mathrm{pH}$ meter and Corning conductivity meter.

Dissolved oxygen was determined with azide modification of the Winkler Method (Golterman et al., 1978). The total alkalinity and $\mathrm{CO}_{2}$ were determined according to Golterman et al. (1978) and Mackereth et al. (1978), respectively.

The dissolved nutrients, total phosphorus, nitrite, nitrate and ammonia were determined in the laboratory according to the techniques in Golterman et al. (1978) and Koroleff, (1976). Chlorophyll a was determined according to the technique described in Golterman et al. (1978).

TABLE 1

The parameters, of tanks A, B, C, D, E and F, used in the experiments.

\begin{tabular}{|c|c|c|}
\hline \multirow{2}{*}{$\begin{array}{c}\text { Stock Density } \\
\left(\text { fish } / \mathbf{m}^{\mathbf{2}}\right)\end{array}$} & \multicolumn{2}{|c|}{ Protein Levels } \\
\cline { 2 - 3 } & $\mathbf{1 6 \%}$ & $\mathbf{3 4 \%}$ \\
\hline 0.25 & $\mathrm{~A}$ & $\mathrm{D}$ \\
\hline 0.50 & $\mathrm{~B}$ & $\mathrm{E}$ \\
\hline 0.75 & $\mathrm{C}$ & $\mathrm{F}$ \\
\hline
\end{tabular}


The residence time of water was estimated by dividing the volume of tanks by the obtained inflow.

\section{Data analysis}

Temperature and residence time in the fish tanks were analyzed utilizing a single classification ANOVA with equal sample sizes, at 0.05 significant level. In the cases where there was significant difference, it was utilized an average test a posteriori (LSD, least square differences).

The other limnological characteristics such as water transparence, $\mathrm{pH}$, dissolved oxygen, conductivity, alkalinity, bicarbonate, free $\mathrm{CO}_{2}$, total $\mathrm{CO}_{2}$, ammonia, nitrite, nitrate, total phosphorus and chlorophyll a were combined in two treatments, stock density and protein levels in ration analized as function of experiment lenght (Table 1). A threeway factorial ANOVA was used to analyze the data, at 0.05 significance level. Statistical development followed according to Sokal \& Rohlf (1981).

\section{RESULTS AND DISCUSSION}

Fish farming enriches the organic and inorganic material in the water column, through the addition of faeces, excretion, uneaten food, desquamations, mucus, vitamins and therapeutic agents and may also have implications for possibles effects in the water quality.

One common solution for this is to flush the ponds with large amounts of fresh water.
According to Avnimelech et al. (1992), this factor acts on the nutrient cycle in the system, causing alterations of physical-chemical and biological variables due to the constant circulation of water.

Generally, residence time was found to be short with a variation of 0.5 to 4.5 days, the influence of which was evident in the water transparency of the water in the tanks studied (Fig. 1). There was no significant difference in water residence time in the tanks $(P>0.05)$ during experiment period (Table 3 ).

Secchi disk visibility for the test period in tanks with $16 \%$ protein levels were lower than those in tanks with $34 \%$ protein levels. The low water transparency in tank $\mathrm{E}$ were due to higher chlorophyll a (Fig. 1 and Table 4).

In catfish cultivation, Ghate et al. (1993) observed that densities of 12,500 to $37,500 \mathrm{fish} /$ ha did not affect nutrient concentrations in the environment due to the continual water flow in the tanks.

The levels of dissolved oxygen (DO) in tanks is influenced by biotic and abiotic factors in the environment. However, in tanks with short residence time and with water exiting from the bottom, as in the tanks studied, mixing oxygen in the hypolimnion, keeping DO values higher than $4 \mathrm{mg} / \mathrm{L}$.

The bottom exit also carries dissolved nutrients and, consequently, leads to a decrease in the primary production of system.

TABLE 2

Results from variance analysis for temperature of the tanks, during the study and LSD test.

\begin{tabular}{|l|c|c|c|c|}
\hline Source of Variation & gl & SS & MS & Fs \\
\hline Among Groups & 5 & 221.785 & 44.357 & 37.59 \\
\hline Within Groups & 30 & 35.458 & 1.18 & \\
\hline Total & 35 & 257.243 & & \\
\hline $\mathrm{F}_{0.05(5.30)}=2.53$ & & & & \\
\hline $\mathrm{X}_{1}=$ February & $\begin{array}{l}\mathrm{X}_{2}=\text { January } \\
27.5\end{array}$ & $\begin{array}{l}\mathrm{X}_{3}=\text { March } \\
26.5\end{array}$ & $\begin{array}{l}\mathrm{X}_{4}=\text { April } \\
26.2\end{array}$ & $\begin{array}{l}\mathrm{X}_{5}=\text { May } \mathrm{X}_{6}=\text { June } \\
\underline{23.0} \underline{20.7}\end{array}$ \\
\hline
\end{tabular}

$\mathrm{X}_{1 \ldots 6}=$ months 
TABLE 3

Results from variance analysis for residence time of the tanks during the study.

\begin{tabular}{|l|c|c|c|c|}
\hline $\begin{array}{l}\text { Source of } \\
\text { Variation }\end{array}$ & gl & SS & MS & Fs \\
\hline Among Groups & 5 & 5.253 & 1.051 & $2.367 \mathrm{~ns}$ \\
\hline Within Groups & 30 & 13.318 & 0.444 & \\
\hline Total & 35 & 18.571 & & \\
\hline $\mathrm{F}_{0.05(5.30)}=2.53$ & \\
\hline
\end{tabular}

$\mathrm{ns}=$ not significant

TABLE 4

Mean values for nutrient $(\mu \mathrm{g} / \mathrm{L})$ and chlorophyll a $(\mu \mathrm{g} / \mathrm{L})$ in the different tanks studied $\left(\mathrm{CP}\right.$ - crude protein and $0.25 ; 0.50$ and $0.75 \mathrm{fish} / \mathrm{m}^{2}$ ).

\begin{tabular}{|c|c|c|c|c|c|c|}
\hline \multirow{2}{*}{$\begin{array}{c}\text { Limnological } \\
\text { Characteristics } \\
(\mu \mathbf{g} / \mathbf{L})\end{array}$} & \multicolumn{5}{|c|}{$\mathbf{1 6 \% \mathbf { C P }}$} \\
\cline { 2 - 7 } & $\mathbf{A}(\mathbf{0 . 2 5})$ & $\mathbf{B}(\mathbf{0 . 5 0})$ & $\mathbf{C}(\mathbf{0 . 7 5})$ & $\mathbf{D}(\mathbf{0 . 2 5})$ & $\mathbf{E}(\mathbf{0 . 5 0})$ & $\mathbf{F}(\mathbf{0 . 7 5})$ \\
\hline Ammonia & 68.2 & 67.5 & 63.3 & 78.1 & 82.9 & 180.0 \\
\hline Nitrate & 43.2 & 55.0 & 53.0 & 42.0 & 35.0 & 62.1 \\
\hline Nitrite & 3.3 & 10.2 & 17.7 & 1.3 & 0.7 & 2.7 \\
\hline $\begin{array}{c}\text { Total } \\
\text { Phosphorus }\end{array}$ & 295.8 & 140.0 & 200.0 & 141.3 & 815.0 & 829.0 \\
\hline Chlorophyll a & 5.1 & 8.7 & 4.8 & 5.6 & 11.5 & 6.1 \\
\hline
\end{tabular}

Temperature and oxygen solubility did not show a negative correlation, although temperature is well known to influence oxygen solubility. The temperature varied from 18 to $30^{\circ} \mathrm{C}$, water temperature at harvest averaged $25.2^{\circ} \mathrm{C}$. The small volume of water in these tanks and hot period, during the beginning was quickly heated by the sun. The water temperature change significantly during studied period $(\mathrm{P}<0.05)$, decreasing gradually from summer to winter (Fig. 1 and Table 2).

Temperature and DO variations are more pronounced in shallow artificial systems such as tanks and reservoirs, than in natural lakes.

This is due to the influx of water that normally forms density currents that can greatly alter the DO regime and temperature. Water temperature has considerable regulatory influence on tank productivity.

Another factor that is affected by temperature is fish metabolism. According to Borghetti \& Canzi (1993), temperatures above $24^{\circ} \mathrm{C}$ leads fish to ingest several different food sources. This probably relates to the fact that the $34 \%$ level of crude protein showed satisfactory results regarding the limnological characteristics studied, when the recommended level for maintenance of adequate levels of water quality is $27 \%$ to $28 \%$ of crude protein.

Normally, the effect of fish food in the environment is more associated to the quantity and the frequency that it is offered to the fish. Other factors such as feeding behavior, developmental phase and physical conditions of the cultivated fish have direct influence on food ingestion.

This way, that nutrients released from uneaten feed and fish feces by bacteria decomposition helped maintain plankton in the ponds for longer periods, and this will act directly on the water quality.

The $\mathrm{pH}$ of water was observed to have a direct relation to DO and inversely proportionate to the bicarbonate and alkalinity (Figs. 1 and 2). Normally, the $\mathrm{pH}$ maintained a slight acid to alkaline aspect, due to the water supply that came from a dam where fish were cultivated and where the $\mathrm{pH}$ varies from 6.1 to 7.1 (Sipaúba-Tavares \& Durigan, 1995). 


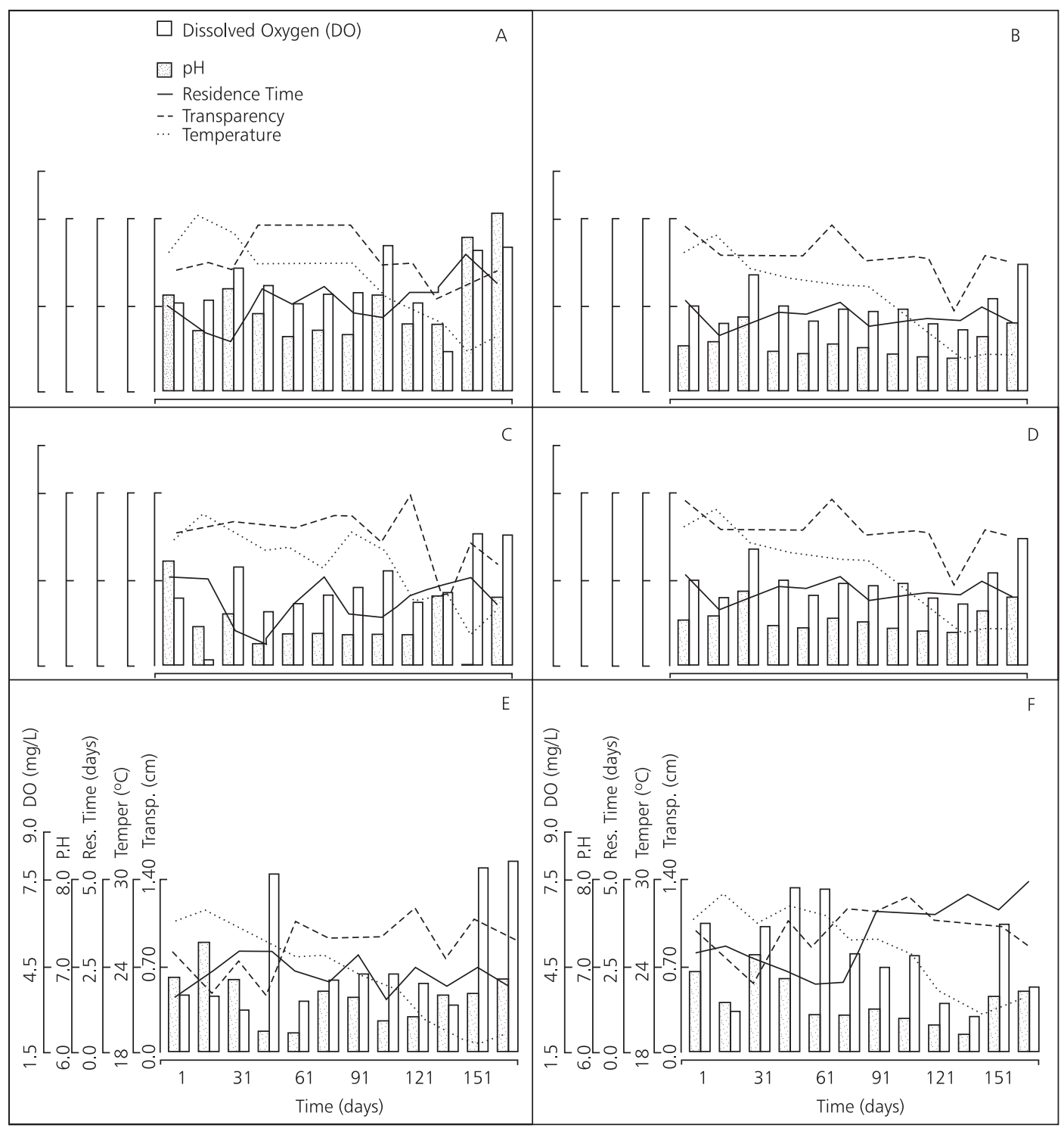

Fig. 1 - Limnological characteristics of the water column in the six tanks studied, where: A, B and C had 16\% crude protein (CP) and D, E and F had $34 \%$ crude protein (CP) at densities of $0.25 ; 0.50$ and $0.75 \mathrm{fish} / \mathrm{m}^{2}$, respectively.

Six tanks studied, free carbon dioxide was more often available which converts the insoluble calcium carbonate into soluble calcium bicarbonate. Consequently the six tanks exhibits higher bicarbonate content (Fig. 2). A very close relationship is found between carbonate content and $\mathrm{pH}$, both of them go strictly hand in hand, and an inverse relationship between carbonate and bicarbonate is found to exist in the tanks water studied.

The alkalinity fluctuations observed during the period of study (Fig. 2) are connected to the ions present in the environment and can also occur because of high bacterial decomposition that would lead to the production of great quantities of $\mathrm{CO}_{2}$. This would then increase the solubility of the calcium carbonate originating from the sediment.

Conductivity values varied from 21 to 40 $\mu . S / \mathrm{cm}$ in the tanks studied (Fig. 2), although they were relatively low when compared to those of Sipaúba-Tavares \& Durigan (1995) using the same kind of systems. 


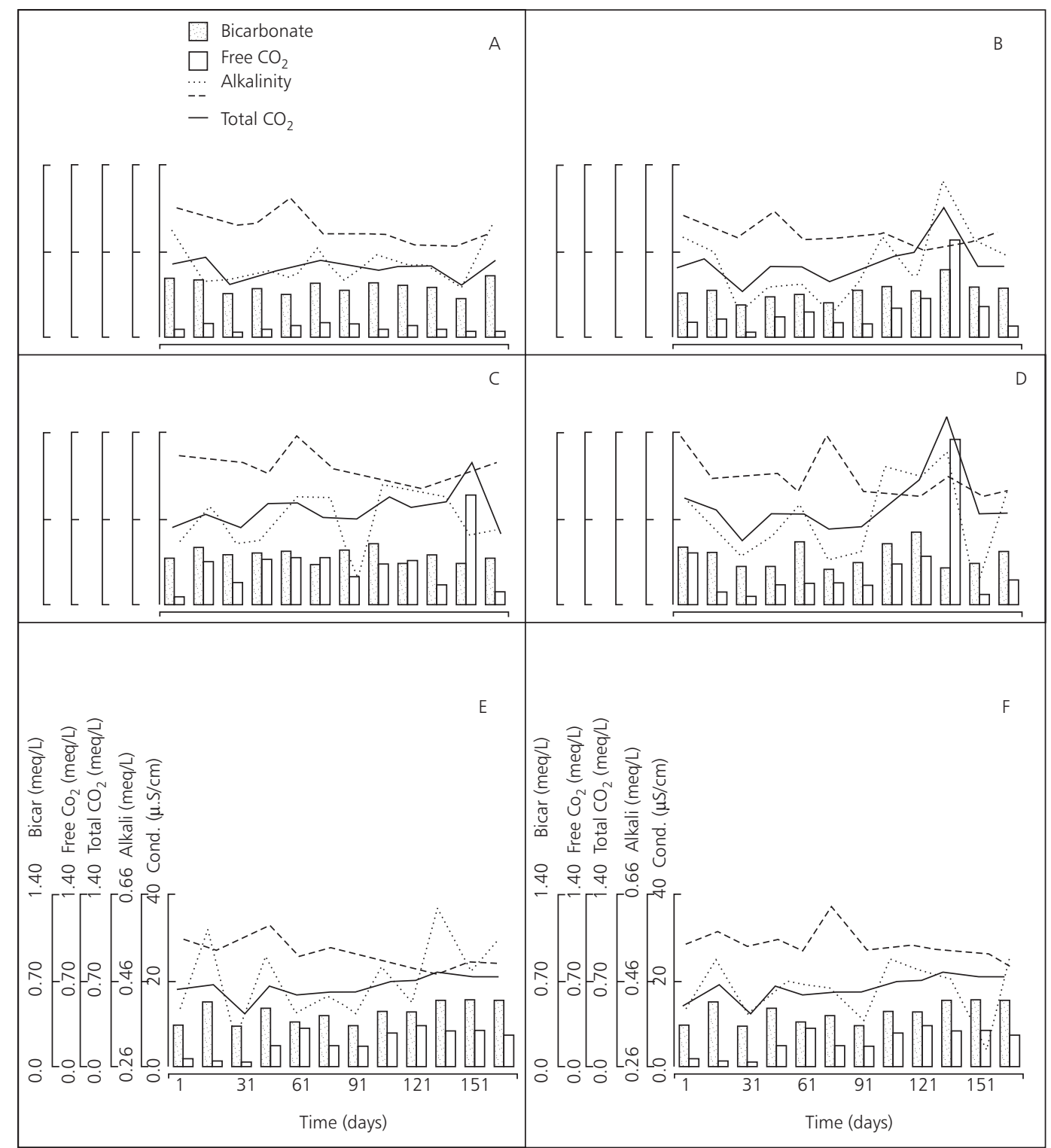

Fig. 2 - Limnological characteristics of the water column in the six tanks studied, where: A, B and C, had 16\% crude protein (CP) and D, E and F had $34 \%$ crude protein $(\mathrm{CP})$ at densities of $0.25 ; 0.50$ and $0.75 \mathrm{fish} / \mathrm{m}^{2}$, respectively.

These low values can be attributed to the short residence time of the water that, consequently, caused a decrease in ion concentrations in the environment.

Seasonal changes in tank water quality may also have implications he nutrients concentrations.

Among the nitrogenous compounds (Table 4), ammonia presented the highest concentrations, probably because of the decomposition of organic material, excretion by fish and uneaten feed that, in these environments, are extremely high.

According to Avault (1993), high fish densities leads to an increase of ammonia levels in the environment due to fish excretion and daily feeding. However, in this study, density was not the determinant factor regarding this nutrient.

Tanks rarely react in the same way, even when stocked and fed similarly. Small differences in the 
water supply, the soil, water and the type of pond or tank, among other factors affect the abiotic factors, making them completely different.

In the water body the ammonia, nitrite and nitrate concentrations rose upon refilling the tank. This could possibly be attributed to diffusion from the sediment. The concentration of all three compounds decreased with time due to the rapid and effective assimilation by algae (Table 4).

Bosstrom (1981) showed that phytoplankton may compete with nitrifying bacteria for ammonia and that nitrate produced can also be rapidly consumed by phytoplankton

The low nitrite concentrations found could be associated to the predominance of bicarbonate in the environment which causes the decrease of this element in the water. Nitrite is intermediate in oxidation state between ammonia and nitrate, its concentration in oxygenated water is typically low.

Regarding total phosphorus the high concentrations in relation of nitrogenous compounds (Table 4), was due to excretion by fish and the partially digested feed have a high phosphorus content and occurs in a number of forms, affecting water quality because increases primary productivity and it is available for phytoplankton growth.

Small fish may recycle more phosphorus than large fish on a mass specific basis. Fish movements also affect the relative importance of nutrient excretion by fish (Mather et al., 1995).

In the cultivation of tilapia fish, Diana et al. (1991) no verified significant differences in nutrient and chlorophyll a concentrations with a density of $1 \mathrm{fish} / \mathrm{m}^{3}$, but densities beyond $8 \mathrm{fish} / \mathrm{m}^{2}$ have been to be detrimental to the fish due to the build up of waste metabolites in pond water (Zohar et al., 1984).

In this study, chlorophyll a was directly related to water flow and transparency (Table 4). These probably caused a loss of phytoplanktonic biomass in the environment. According to Tundisi (1988), the frequency and duration of algae growth in shallow systems, basically depends on the residence time of the mass of water since part of the planktonic population is removed by the unidirectional flow of water, being responsible for the absence of real plankton.

A relatively short residence time in small tanks directly affects the dynamics of the environment. This way, the effect of fish density and the kind of feed offered was found to directly influence some limnological characteristics analyzed since the chemical and biological processes are intimately linked to the continuous water flow.

The interaction between stocking density and experiment duration interfered with bicarbonate concentration and alkalinity. On the other hand, interaction between stock density and protein levels affected total and free $\mathrm{CO}_{2}$ concentrations, conductivity, and $\mathrm{pH}$. All the other limnological characteristics were not affected by treatments during the experiment (Table 5).

Several basic improvements in the manufacture of diets have taken place over the last decade to minimize common water quality effects. Most feed formulations have tended to reduce the protein content using energy sources such as lipids and increase the fat level, resulting in a decrease in the nitrogen discharge per $\mathrm{Kg}$ of fish produced (Silva \& Anderson, 1995).

Ponds are inherently variables ecosystems and management of ponds is largely an attempt to control the chemical and biological process in ponds. The present study the stock density and pressed feed maintained water quality within acceptable limits.

Acknowledgments - The authors thank FUNDAP (Foundation for Research Support) and FAPESP (São Paulo Foundation for Research Support) for their financial support. They would also like to thank Silvia Regina L. de Laurentiz for her help in the field work. 
TABLE 5

Relationship between limnological characteristics and treatments.

\begin{tabular}{|c|c|c|c|c|}
\hline Characteristics & Stock Density & Protein Levels & Period & Fs \\
\hline & $\mathrm{X}$ & & $\mathrm{X}$ & $0.717 \mathrm{~ns}$ \\
\hline \multirow[t]{3}{*}{ Transparency } & $\mathrm{X}$ & $\mathrm{X}$ & & $1.429 \mathrm{~ns}$ \\
\hline & & $\mathrm{X}$ & $\mathrm{X}$ & $0.460 \mathrm{~ns}$ \\
\hline & $\mathrm{X}$ & & $\mathrm{X}$ & $1.11 \mathrm{~ns}$ \\
\hline \multirow[t]{3}{*}{$\mathrm{pH}$} & $\mathrm{X}$ & $\mathrm{X}$ & & $6.67^{*}$ \\
\hline & & $X$ & $\mathrm{X}$ & $0.28 \mathrm{~ns}$ \\
\hline & $\mathrm{X}$ & & $\mathrm{X}$ & $0.54 \mathrm{~ns}$ \\
\hline \multirow[t]{3}{*}{ Dissolved Oxygen } & $\mathrm{X}$ & $\mathrm{X}$ & & $0.94 \mathrm{~ns}$ \\
\hline & & $\mathrm{X}$ & $\mathrm{X}$ & $0.34 \mathrm{~ns}$ \\
\hline & $\mathrm{X}$ & & $\mathrm{X}$ & $0.86 \mathrm{~ns}$ \\
\hline \multirow[t]{3}{*}{ Conductivity } & $\mathrm{X}$ & $\mathrm{X}$ & & $7.46^{*}$ \\
\hline & & $\mathrm{X}$ & $\mathrm{X}$ & $1.35 \mathrm{~ns}$ \\
\hline & $\mathrm{X}$ & & $\mathrm{X}$ & $6.00^{*}$ \\
\hline \multirow[t]{3}{*}{ Alkalinity } & $\mathrm{X}$ & $\mathrm{X}$ & & $2.00 \mathrm{~ns}$ \\
\hline & & $\mathrm{X}$ & $\mathrm{X}$ & $5.00^{*}$ \\
\hline & $\mathrm{X}$ & & $\mathrm{X}$ & $4.00^{*}$ \\
\hline \multirow[t]{3}{*}{ Bicarbonate } & $\mathrm{X}$ & $\mathrm{X}$ & & $3.00 \mathrm{~ns}$ \\
\hline & & $\mathrm{X}$ & $\mathrm{X}$ & $2.50 \mathrm{~ns}$ \\
\hline & $\mathrm{X}$ & & $\mathrm{X}$ & $0.95 \mathrm{~ns}$ \\
\hline \multirow[t]{3}{*}{ Free $\mathrm{CO}_{2}$} & $\mathrm{X}$ & $\mathrm{X}$ & & $5.20^{*}$ \\
\hline & & $\mathrm{X}$ & $\mathrm{X}$ & $1.30 \mathrm{~ns}$ \\
\hline & $\mathrm{X}$ & & $\mathrm{X}$ & $0.67 \mathrm{~ns}$ \\
\hline \multirow[t]{3}{*}{ Total $\mathrm{CO}_{2}$} & $\mathrm{X}$ & $\mathrm{X}$ & & $7.94^{*}$ \\
\hline & & $\mathrm{X}$ & $\mathrm{X}$ & $1.25 \mathrm{~ns}$ \\
\hline & $\mathrm{X}$ & & $\mathrm{X}$ & $0.61 \mathrm{~ns}$ \\
\hline \multirow[t]{3}{*}{ Ammonia } & $\mathrm{X}$ & $\mathrm{X}$ & & $1.62 \mathrm{~ns}$ \\
\hline & & $\mathrm{X}$ & $\mathrm{X}$ & $0.22 \mathrm{~ns}$ \\
\hline & $\mathrm{X}$ & & $\mathrm{X}$ & $1.14 \mathrm{~ns}$ \\
\hline \multirow[t]{3}{*}{ Nitrate } & $\mathrm{X}$ & $\mathrm{X}$ & & $0.12 \mathrm{~ns}$ \\
\hline & & $\mathrm{X}$ & $\mathrm{X}$ & $1.01 \mathrm{~ns}$ \\
\hline & $\mathrm{X}$ & & $\mathrm{X}$ & $1.08 \mathrm{~ns}$ \\
\hline \multirow[t]{3}{*}{ Nitrite } & $\mathrm{X}$ & $\mathrm{X}$ & & $2.38 \mathrm{~ns}$ \\
\hline & & $\mathrm{X}$ & $\mathrm{X}$ & $1.17 \mathrm{~ns}$ \\
\hline & $\mathrm{X}$ & & $\mathrm{X}$ & $0.90 \mathrm{~ns}$ \\
\hline \multirow[t]{3}{*}{ Total Phosphorus } & $\mathrm{X}$ & $\mathrm{X}$ & & $2.24 \mathrm{~ns}$ \\
\hline & & $\mathrm{X}$ & $\mathrm{X}$ & $0.42 \mathrm{~ns}$ \\
\hline & $\mathrm{X}$ & & $\mathrm{X}$ & $1.09 \mathrm{~ns}$ \\
\hline \multirow[t]{2}{*}{ Chlorophyll a } & $\mathrm{X}$ & $\mathrm{X}$ & & $0.45 \mathrm{~ns}$ \\
\hline & & $\mathrm{X}$ & $\mathrm{X}$ & $2.94 \mathrm{~ns}$ \\
\hline $\mathrm{F}_{0.05(10.10)}=2.97$ & & $\mathrm{~F}_{0.05(2.10)}=4.10$ & & $\mathrm{~F}_{0.05(5.10)}=3.35$ \\
\hline
\end{tabular}

$\mathrm{ns}=$ not significant

$*=\mathrm{P}<0.05$ 


\section{REFERENCES}

AVAULT, J. W., 1993, Water management in ponds, some basics reviewed: Ammonia and nitrite. Aquaculture Magazine, (may/june): 76-80.

AVNIMELECH, Y., MOZES, N. \& WEBER, B., 1992, Effects of aeration and mixing on nitrogen and organic matter transformation in simulated fish ponds. Aquacult. Eng., 11: 157-169.

BORGHETTI, J. R. \& CANZI, C., 1993, The effect of water temperature and feeding rate on the growth rate of pacu (Piaractus mesopotamicus) raised in cages. Aquaculture, 114: 93-101.

BOSSTROM, B., 1981, Factors controlling the seasonal variation of nitrate in Lake Erken. Int. Revue. Ges. Hydrobiol., 66: 821-836.

DIANA, J. S., DETTWEILER, D. J. \& LIN, C. K., 1991, Effect of nilo tilapia (Oreochromis niloticus) on the ecosystem of aquaculture ponds, and its significance to the trophic cascade hypothesis. Can. J. Fish. Aquat. Sci., 48: 183-190.

GHATE, S. R., BURTLE, G. J. \& SMITH, M. C., 1993, Water quality in catfish ponds subjected to high stocking density selective harvesting production practice. Aquacult. Eng., 12: 169-181.

GOLTERMAN, H. L., CLYMO, R. S. \& OHNSTAND, M. A. M., 1978, Methods for physical \& chemical analysis of fresh waters. Blackwell Sci. Publ., London, 213p.

KOROLEFF, F., 1976, Determination of nutrients. In: K. Grassnof (ed.), Methods of sea water analysis. Verlag Cemie. Weinhein., New York.
MACKERETH, F. J. H., HERON, J. \& TALLING, J. F., 1978, Water analysis: Some revised methods for limnologists. Freshwater Biological Association Scientific Publication no 36, Titus Wilson \& Sons Ltda, London, 121p.

MATHER, M. E., VANNI, M. J., WISSING, T. E., DAVIS, S. A. \& SCHAUS, M. H., 1995, Regeneration of nitrogen and phosphorus y bluegill and gizzard shad: effect of feeding history. Can. J. Fish. Aquat. Sci., 52: 23272338 .

SILVA, S de \& ANDERSON, T. A., 1995, Fish Nutrition in Aquaculture. Chapman \& Hall, London, 319p.

SIPAÚBA-TAVARES, L. H. \& DURIGAN, J. G., 1995 , Variação dos fatores abióticos e pigmentos totais em dois viveiros de criação de peixes em regime semi-intensivo. Acta. Limnol. Brasil., VII: 10-22.

SOKAL, R. R. \& ROHLF, F. J., 1981, Biometry; The principles and practice of statistics in biological research. W. H. Freeman and Company, San Francisco, 857p.

TUNDISI, J. G., 1988, Impactos ecológicos da construção de represas: aspectos específicos e problemas de manejo. In: J. G. Tundisi (ed.), Limnologia e Manejo de Represas. São Carlos, São Paulo.

ZOHAR, G., RAPPAPORT, U., AVNIMEECH, Y. \& SARIG, S., 1984, Results experiments carried out in the Genosar experimental station in 1983: cultivation of tilapia in high densities and with periodic flushing of the pond water. Bamidgeh, 36: 63-69. 